\title{
MÚSICA E MULHER: EFEITOS DE VIOLÊNCIA PATRIARCAL DE GÊNERO
}

\section{MUSIC AND WOMEN: EFFECTS OF PATRIARCHAL GENDER VIOLENCE}

\author{
Dantielli Assumpção Garcia \\ Elaine Pereira Daróz \\ Jaqueline Denardin \\ Maria Eduarda Alves da Silva \\ Lucília Maria Abrahão e Sousa
}

\begin{abstract}
RESUMO: Neste trabalho, a partir da perspectiva teórica da Análise de Discurso e mobilizando a noçăo de memória (PÊCHEUX, 1999), analisaremos como a campanha "Música: uma construçáo de gênero", produzida pela Secretaria de Políticas para Mulheres, de Săo Leopoldo (RS), ao retomar trechos de músicas populares brasileiras e exporem corpos de mulheres vítimas de violência, coloca em funcionamento dizeres estabilizados e legitimados em nossa sociedade acerca da violência patriarcal de gênero (SAFFIOTI, 1994; SAFFIOTI, ALMEIDA, 1995), pontualmente, da violência do homem contra a mulher. Analisaremos como a campanha dá espaço para a confrontaçáo desses dizeres, intentando desestabilizar uma cultura do ódio e violência em relaçáo à mulher.
\end{abstract}

PALAVRAS-CHAVE: Mulher. Música. Violência. Análise de Discurso.

ABSTRACT: On this paper, supported by Discourse Analysis and mobilizing the notion of memory (Pêcheux,1999), we are going to analyse how the avertisement "Música: uma construçăo de gênero", produced by Secretary of Politics for women, from Sáo Leopoldo (RS) which, returning excerpts from Brazilian popular musics and exposing women's bodies victimed by violence, put in functioning stabilized discourses and legitimed in our society concerned with patriarchal of genre (SAFFIOTI,1994; SAFFIOTI, ALMEIDA, 1995), punctually, the violence of the man against woman. In the gesture, we aim to analyze how this advertisement opens up possibilities for confrontation of these discourses by trying to destabilize a culture of hate and violence in relation to the woman.

KEYWORDS: Woman. Music. Violence. Discourse analysis 


\section{DIZERES INICIAIS}

A violência patriarcal de gênero, especificamente a violência masculina contra a mulher, manifesta como aponta Saffioti (1994) em diversas sociedades falocêntricas, é extensamente tolerada por ser praticada por homens. Todavia, "o inimigo da mulher năo é propriamente o homem, mas a organizaçăo social de gênero cotidianamente alimentada năo apenas por homens, mas também por mulheres" (SAFFIOTI, ALMEIDA, 1995, s.p.). Segundo Santos e Izumino (2014), a dominaçăo patriarcal compreende violência como expressâo e representaçâo do modelo de patriarcado, em que a mulher é vista como indivíduo social independente, porém, historicamente é vitimada pelo controle social do poder masculino, uma ideologia em que a posiçâo feminina é colocada como inferior à condiçấo masculina. Essas diferenças se transformam em desigualdades hierárquicas, por intermédio de enunciados masculinos referidos à mulher, atingindo especificamente o corpo dela. Fenômeno ainda pouco estudado o da violência contra a mulher - há cerca de duas décadas, tem ganhado espaço nas/ graças às pautas feministas nas quais

vêm-se levantando dados sobre ele em vários países, fazendo-se pesquisas sobre o contexto de sua produçăo e divulgando-se hipóteses e conclusôes. Também se estăo implementando políticas públicas que, por um lado, dăo guarida a mulheres vítimas de espancamento, estupro, ameaça de morte, e, por outro, pressionam as autoridades policiais e judiciárias, visando à reduçấo das altíssimas cifras de impunidade. (SAFFIOTI, ALMEIDA, 1995, p. 4)

Diante desse contexto sócio-histórico-ideológico, que busca evidenciar a violência patriarcal de gênero, analisaremos, neste trabalho, uma campanha realizada pela Secretaria de Políticas para Mulheres, de Săo Leopoldo (RS), intitulada "Música: uma construçâo de gênero". Nessa campanha, temos fotografias de mulheres com marcas de violências em seus corpos, que seguram cartazes com dizeres de músicas brasileiras, as quais cantam, em forma de samba, funk, axé, que violentariam a mulher com estupro, tapas, mortes.

Para compreendermos essa campanha, nosso texto divide-se em três momentos: inicialmente, discutiremos acerca da memória na perspectiva discursiva. Após isso, retomando as discussóes propostas por Saffioti (1994) sobre a violência patriarcal de gênero, analisaremos como a violência contra a mulher faz parte da constituiçấo de uma subjetividade feminina. Na continuidade, analisaremos a campanha, buscando perceber como as músicas citadas nos cartazes legitimam e justificam a violência contra a mulher praticada pelo homem.

\section{UM POUCO DE MEMÓRIA E MULHER}

Nas relaçōes cotidianas, somos frequentemente assaltados por lembranças de pessoas, atos, palavras; atribuindo-lhes mais ou menos valor, a depender das condiçôes nas quais foram vivenciadas, e das posiçōes em que nos encontrávamos ou nos encontramos ao rememorá-las. Por essas lembranças dos dizeres e dos fazeres cotidianos, somos levados a crer em uma unidade de sentidos, no poder de nossas escolhas. Segundo Pêcheux (1999, p.33), esse suposto controle total sobre o que se diz e se faz é uma ilusâo 
necessária ao sujeito pragmático face aos anseios de um "mundo semanticamente estabilizado", cujos sentidos se marcam por uma aparente univocidade discursiva. Ilusâo esta resultante da interpelaçâo ideológica constitutiva como condiçâo para ser sujeito, produzindo um efeito de obviedade dos sentidos nos sujeitos discursivos.

Nesse processo de submissăo do sujeito para a produçấo do dizer, conforme Pêcheux (2010[1969]), o que está em jogo é a identificaçăo pela qual todo sujeito se reconhece como homem [...] e como é organizada sua relaçấo com aquilo que o representa. Segundo o autor, a identificaçấo do sujeito se realiza a partir de uma superposiçâo do sujeito enunciador e sua forma-sujeito, sujeito universal, na qual implicam as imagens do sujeito, que se marcam no discurso por mecanismos de antecipaçôes e regras de projeçôes acerca de si mesmo (sujeito enunciador), do objeto do discurso e do interlocutor, concernente a sua tomada de posiçấo no discurso.

Nesse jogo inerente à relaçăo entre sujeito e língua pelo qual o sujeito é convocado a se significar, a mídia atua na circulaçăo/reproduçăo dos dizeres, com vistas à naturalizaçâo de determinados sentidos concernentes às formaçôes ideológicas vigentes. De acordo com Romáo (2012), na mídia, "é tecido o imaginário de que o mundo permanece, dia e noite, em condiçấo de tornar-se relato midiático a ser comercializado, de virar notícia prestes a ser narrada e distribuída...". Os inúmeros dizeres sobre a mulher postos em circulaçăo quer em TV, outdoors, jornal impresso e digital, mídia eletrônica, se marcam sob uma aparente obviedade, produzindo efeitos que se materializam nas práticas dos sujeitos contemporâneos. No entanto, o que faz com que determinados sentidos se fixem na formaçăo social, em detrimento de outros que vấo sendo esquecidos /apagados?

De acordo com Pêcheux (2010 [1969]), os discursos săo estruturados na relaçăo entre memória e atualidade, e se marcam no funcionamento discursivo por processos parafrásticos - na repetiçăo do mesmo em diferentes discursividades, possibilitada pela regularizaçáo dos sentidos no nível interdiscursivo - ou, ainda, por processos polissêmicos, que se realizam por meio de deslocamentos, deslizamentos, permitindo a inscriçấo de sentidos outros possíveis concernentes a uma dada conjuntura na formaçăo social (ORLANDI, 2009). Sendo assim, a memória ocupa papel preponderante na regularizaçâo dos sentidos a serem regularizados em nossa formaçáo social. De acordo com Mostafa, Amorim e Sousa (2014, p. 16), esse "papel da memória opera de modo a sustentar a possibilidade de todo dizível, a inscriçăo de toda e qualquer palavra já que tanto o efeito de regularizaçăo quanto o de ruptura depositam-se sobre/sob as palavras já ditas por outrem". Na ordem do repetível, se coloca em jogo a tensăo constitutiva que se estabelece na relaçăo entre sujeitos e sentidos, materializada, nas palavras dos autores, no "encontro de redes de dizeres e de efeitos em redes", que se marca na e pela língua, no discurso, portanto (Mostafa, Amorim, Sousa, 2014, p. 17).

No discurso midiático (impresso e digital), os dizeres sobre as mulheres se marcam, de um modo geral, por temáticas relativas à política, moda, beleza, violência dentre outras, materializando sentidos acerca da posiçăo da mulher frequentemente posta em relaçăo ao outro, o homem, bem como acerca de status social. A partir de um efeito de evidência, se presentificam nos dizeres que circulam na mídia năo apenas os sentidos acerca do que a mulher pode ou náo dizer, mas também sobre o que ela deve ou nâo fazer. A naturalizaçâo desses dizeres possibilita um imaginário de mulher a partir 
de uma representaçăo, com vistas à estabilizaçăo de uma memória sobre a mulher na atualidade, intrinsecamente relacionada à posiçáo que ela deve ocupar na formaçáo social. No entanto, segundo Pêcheux (1999[1983], p.56), a memória é um "espaço móvel de disjunçấo, de deslocamentos e de retomadas, de conflitos de regularizaçăo, um espaço de desdobramentos, réplicas, polêmicas e contra-discursos", concernentes com a tomada de posiçăo do sujeito no discurso. Isto porque, como afirma o autor (PÊCHEUX 2010 [1969]), os sentidos nâo sâo fixos na língua, mas se re(significam) em consonância às redes de filiaçôes sócio-histórico-ideológicas inerentes a cada época, cada formaçấo social. A pensar nos efeitos dos discursos postos em circulaçăo na rede mundial de computadores na atualidade, Romáo (2004, p. 72) afirma que, embora os sentidos se fixem no espaço digital sob "pontos e nós" aparentemente coesos,

[...] há espaços de brechas, desvăos e buracos, que criam poros abertos, por onde escorregam vazios, escampam silêncios, escorrem os náo-ditos e interditos. Há văos intervalares entre os cantos de galo, há espaços vazios entre os pontos de um bordado, há frestas de sentido entre as palavras de um texto, há poros abertos no rendilhado-rede do pescador. 0 desenho e a fissura, a linha e o fio roto, o riscado e a ausência dele, o peixe preso e aquele que escapou. Por isso, além do fio, é constitutiva a falta dele na rede.

As discursividades postas em circulaçâo na mídia regularizam determinados sentidos sobre a mulher a partir de uma voz aparentemente uníssona, a fim de convocar os sujeitos discursivos a tomarem suas posiçôes pré-determinadas na formaçấo social. No entanto, discursivamente compreendemos que sujeitos e sentidos se significam contínua e concomitantemente, no jogo da e pela língua, abrindo espaço para possibilidades outras no dizer. Sob esse viés, tomando as contribuiçôes dos estudos lacanianos (LACAN, 1999), Pêcheux afirma que há sempre algo que escapa, que falha, abrindo lugar para a resistência que é constitutiva do sujeito (PÊCHEUX, 2010 [1969]). Dentre as possibilidades de resistência aos efeitos de sentidos relativamente estabilizados sobre a mulher na atualidade, a rede mundial de computadores têm se mostrado um espaço profícuo para a inscriçăo de novas posiçóes da e para a mulher nos tempos atuais. Em seus estudos sobre a sororidade no ciberespaço, Garcia e Sousa (2015, p. 996) afirmam que, na atualidade, "o sujeito-mulher busca criar espaços de resistência e de militância por um novo dizer sobre o que é ser mulher e sobre o que é feminismo no século XXI". Na luta pela ressignificaçáo de sentidos, a internet se constitui, assim, como um lugar de resistência para o compartilhamento de dizeres feministas que sustentam diferentes lutas das mulheres, com vistas à transformaçấo das práticas sociais.

Mesmo na sociedade em rede, os sentidos năo se regularizam aleatoriamente. De acordo com Orlandi (2005), todo processo discursivo se realiza por meio dos níveis da constituiçâo, formulaçâo e circulaçâo. O nível da constituiçăo consiste em uma memória do dizer para discursividades vindouras, a partir de uma retomada dos sentidos relativamente estabilizados. A formulaçâo, por sua vez, traz à cena às condiçōes sócio-histórico-ideológicas em que os sentidos estâo inscritos, consistindo numa condiçâo favorável para a reatualizaçăo da memória, tendo em vista o irrepetível da língua. Ainda segundo a autora, é no nível da circulaçâo que se dá a materializaçăo dos sentidos nos discursos, em uma dada conjuntura. Em nosso trabalho, propomos uma análise dos dizeres que circularam em uma campanha produzida pela Secretaria de Políticas para Mulheres de Săo Leopoldo intitulada "Música: uma construçăo de gênero". Retomando 
uma memória sobre as relaçôes entre homens e mulheres expressas em músicas brasileiras, a campanha inscreve-se e circula na rede social Facebook, fazendo resistência a dizeres que justificam e legitimam a violência contra a mulher. Desse modo, analisaremos como dizeres sobre (e para) a mulher sâo discursivizados em diferentes estilos musicais em nossa formaçāo social, na medida em que, pensamos, reproduzem um imaginário de mulher, a que deve e merece ser violentada, na atualidade com implicaçôes nas práticas dos sujeitos contemporâneos.

\section{A VIOLÊNCIA PATRIARCAL DE GÊNERO}

A violência masculina contra a mulher, como afirma Saffioti (1994, p. 151), é constitutiva da organizaçâo social de gênero no Brasil. Diríamos que essa violência funciona assentada em uma memória sobre o ser mulher e homem na sociedade patriarcal brasileira, sendo manifestada de diferentes formas, "desde as mais sutis, como a ironia, até o homicídio, passando por espancamento, reproduçáo forçada, estupro etc." (SAFFIOTI, 1994, p. 151). Santos e Izumino (2014) ressaltam que os papéis atribuídos às mulheres e aos homens, que foram firmados ao longo da história, reforçados pelo poder do patriarcado e seu sistema de ideias, levam a relaçôes violentas e abusivas entre os sexos, indicando que esse tipo de violência existe em razăo do processo de socializaçăo dos sujeitos. O desenvolvimento de uma "consciência" crítica da mulher, ressalta Saffioti (1994), tem sido mais rápido do que o do homem, fazendo com que esses deixem de "caminhar pari passu" (SAFFIOTI, 1994, p. 151). Essa contestaçâo feminina do poder masculino tem como consequência o desencadeamento de um processo de violência de consequências imprevisíveis, pois, nesse exercício de uma "cidadania alargada", as assimetrias das relaçóes entre os gêneros tornam-se mais evidentes e gritantes. Todavia, adverte Saffioti (1994, p. 153) que:

A nova atitude de uma parte apreciável das mulheres năo constitui, na verdade, a razăo primeira da violência dos homens contra elas, mas tăo somente o fator desencadeador desta capacidade socialmente legitimada de eles converterem a agressividade em agressăo. Náo houvesse esta sançăo social positiva, as relaçóes de gênero náo descreveriam tăo bruscos movimentos. É exatamente esta legitimaçăo social da violência dos homens contra as mulheres que responde pelo caráter tăo marcadamente de gênero deste fenômeno.

Assim, a violência contra a mulher faz parte da e sustenta a organizaçăo social de gênero vigente na sociedade brasileira, tratando-se da violência "enquanto modalidade material de controle social e de repressăo exercida através de formas 'ideacionais' de socializaçăo" (SAFFIOTI, 1994, p. 154). Como exemplo, as músicas - objeto de campanha pela Secretaria de Políticas para Mulheres de Săo Leopoldo (RS) e de análise de nosso trabalho - que circulam na sociedade brasileira, legitimando e justificando uma violência contra a mulher. A sociedade e o Estado, retomando Saffioti (1994), nâo somente acolhem o poder masculino sobre a mulher como o normatiza, proibindo e até criminalizando seus excessos: "A puniçăo das extravagâncias integra o poder disciplinador da dominaçăo masculina sobre a mulher, exercido pelo Estado. Este năo faz, portanto, senâo ratificar a falocracia em suas dimensōes material e "ideacional", dando-lhe a forma jurídica que caracteriza a dominaçăo legalizada" (SAFFIOTI, 1994, p. 155). Isto é, é essa dominaçăo legalizada que irá justificar a violência contra a mulher, colocando 
esta como responsável e merecedora de tal ato. Nas músicas há um dizer que legaliza e justifica a violência contra a mulher, em virtude dessa "questionar" o poder masculino, o qual a vê tăo-somente como objeto de suas açóes violentas. Vejamos:

\section{4. "PEGA O PAU PARA BATER NA MULHER": A LEGITIMAÇÃO DA VIOLÊNCIA CONTRA MULHER}

Neste ano de 2018, o dia 08 de março, instituído Dia Internacional da Mulher, foi marcado por diversas campanhas em prol do combate à(s) violência(s) contra a mulher. Porém, dentre essas, uma se destacou para nós. Realizada pela Prefeitura do Município de Sâo Leopoldo, no estado do Rio Grande do Sul, a campanha "Música: uma construçâo de gênero" utilizou-se de partes de letras de músicas que fizeram e fazem sucesso na sociedade para dizer sobre a violência contra a mulher.

Afirmando ser a música uma forma muito recorrente de/para a construçăo de gênero, a campanha visa, usando imagens de mulheres vítimas de violência, com marcas de hematomas em seus corpos, a produzir um outro sentido para as músicas que circulam na sociedade brasileira, evidenciando serem essas músicas violentas e que legitimam o feminicídio, o estupro, o bater, acreditando na impunidade do homem diante de seus atos violentos contra a mulher.

\section{Figura 1 - "Música: uma construçâo de gênero"}
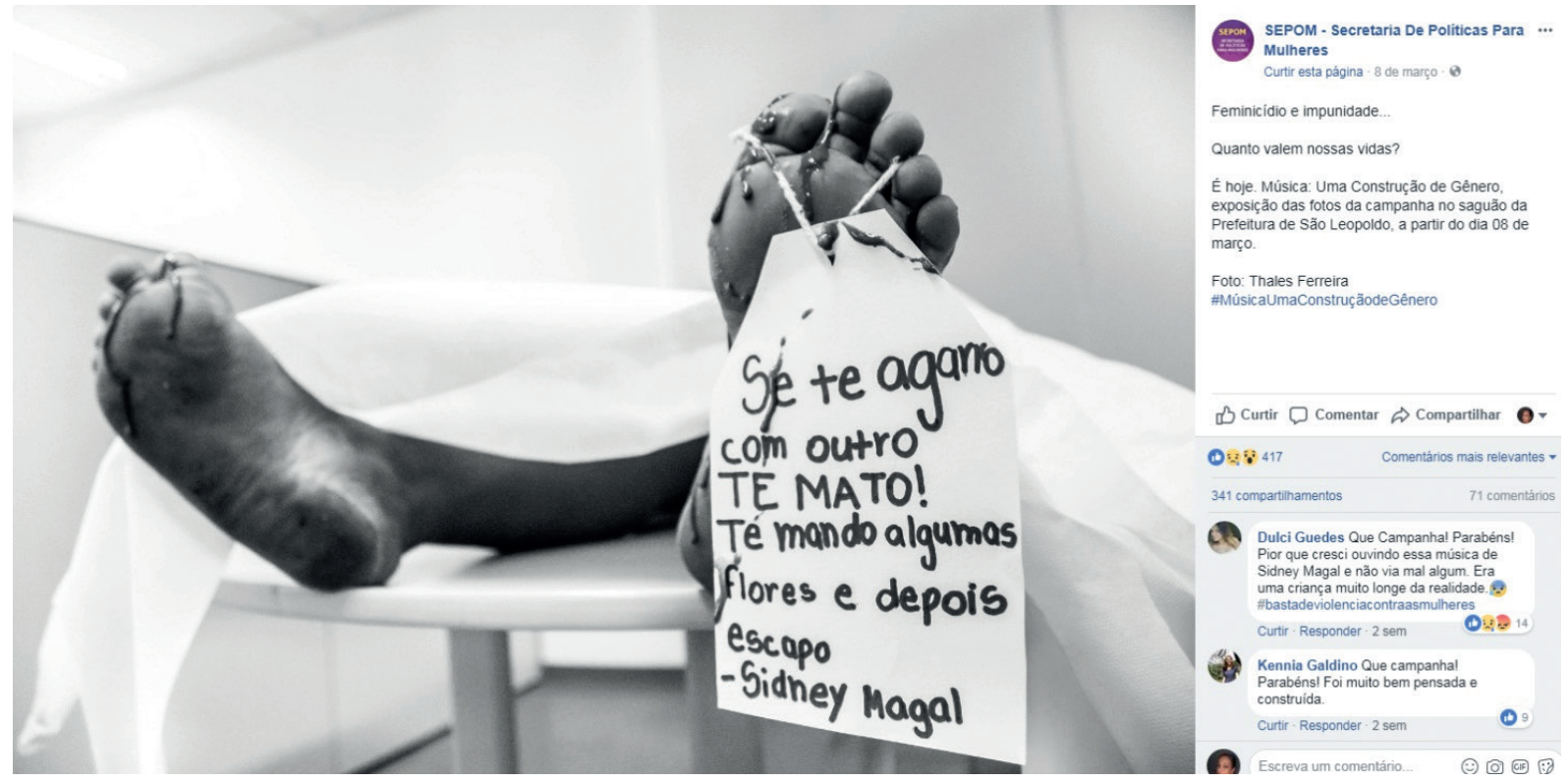

A música de Sidney Magal "Se te agarro com outro te mato" foi o primeiro sucesso do cantor em 1976. Nela, temos um sujeito que canta a violência e justifica o assassinato da mulher, ou melhor, o feminicídio. O motivo, tăo legitimado pela sociedade, seria o ciúme, o ter visto a mulher "com outro". O "mandar algumas flores" é deslocado de uma atitude romântica, por amor para um ato de "homenagem póstuma", ou diríamos 
de "deboche", àquela que foi por esse homem assassinada. Ao escapar, a crença na impunidade do ato que é justificado pela possível traiçáo da mulher, ou seja, legitima-se a possibilidade de executar uma mulher em funçăo da considerada aceita defesa da honra. A violência contra a mulher é na música dissipada e a imagem que circula é a de um homem que seria capaz de matar por amor, por ciúmes. Na imagem, um corpo morto ainda com sangue escorrendo e com uma placa pendurada no dedo como a indicar um cadáver no IML, o que dá a dimensâo de que assassinatos de mulheres ainda hoje ocorrem e săo tidos como possibilidade. Outra música que legitima o feminicídio é o funk dos Mcs Bruninho e Davi.

Figura 2 - "Música: uma construçăo de gênero"

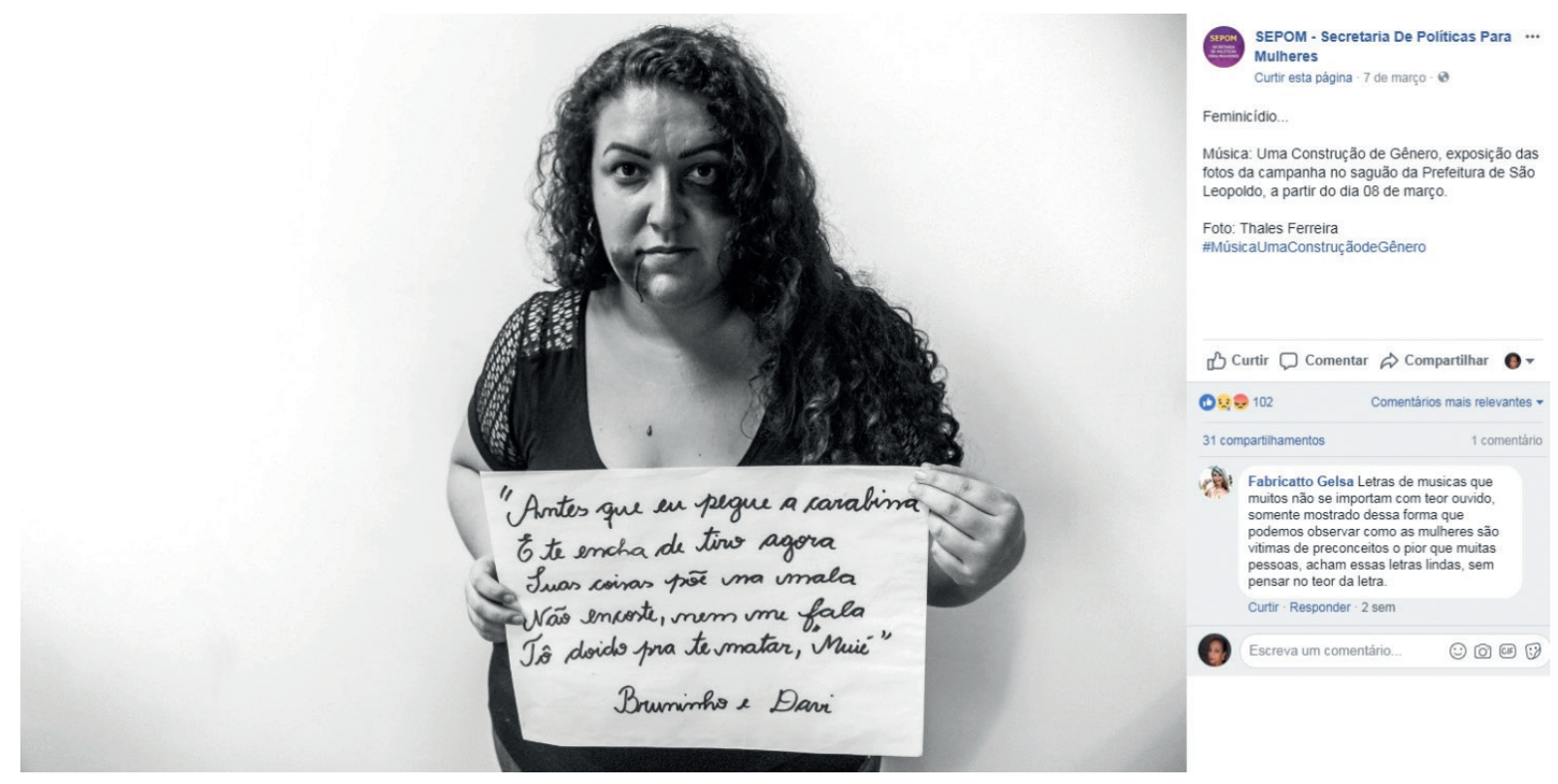

Nele, temos um homem que, aparentemente, expulsa a mulher de casa, ameaçando-a de morte. Aqui, nâo temos evidenciado o "motivo" dessa expulsăo, como na anterior. Só temos o silenciamento dessa mulher que, para năo ser "enchida de tiros", deve, pela ordem do homem, colocar "suas coisas na mala", mostrando que quem mandaria naquele lar seria o homem. É em relaçâo ao seu modo de (nâo) agir que o homem responderá com violência. Sâo as mulheres, como veremos nas músicas, as culpadas pela violência que sofrem, pois "enganou o homem", o traiu, foi ao samba, à rua, ousou dizer năo. Nessas músicas, a mulher é dita pelo homem que a violenta, dizendo amá-la. A imagem do homem nessas cançôes é de um sujeito que age por seus impulsos, instintos, por suas paixóes de devoçâo, ódio e extermínio. A mulher tăo-somente é um objeto para atendê-lo, seja com a vida ou com a morte, ou seja, é objetificada de todos os modos possíveis, nâo lhe restando outro modo de ser falada. O homem já sabe o que fazer com a "mina": matá-la. 
Figura 3 - "Música: uma construçăo de gênero"

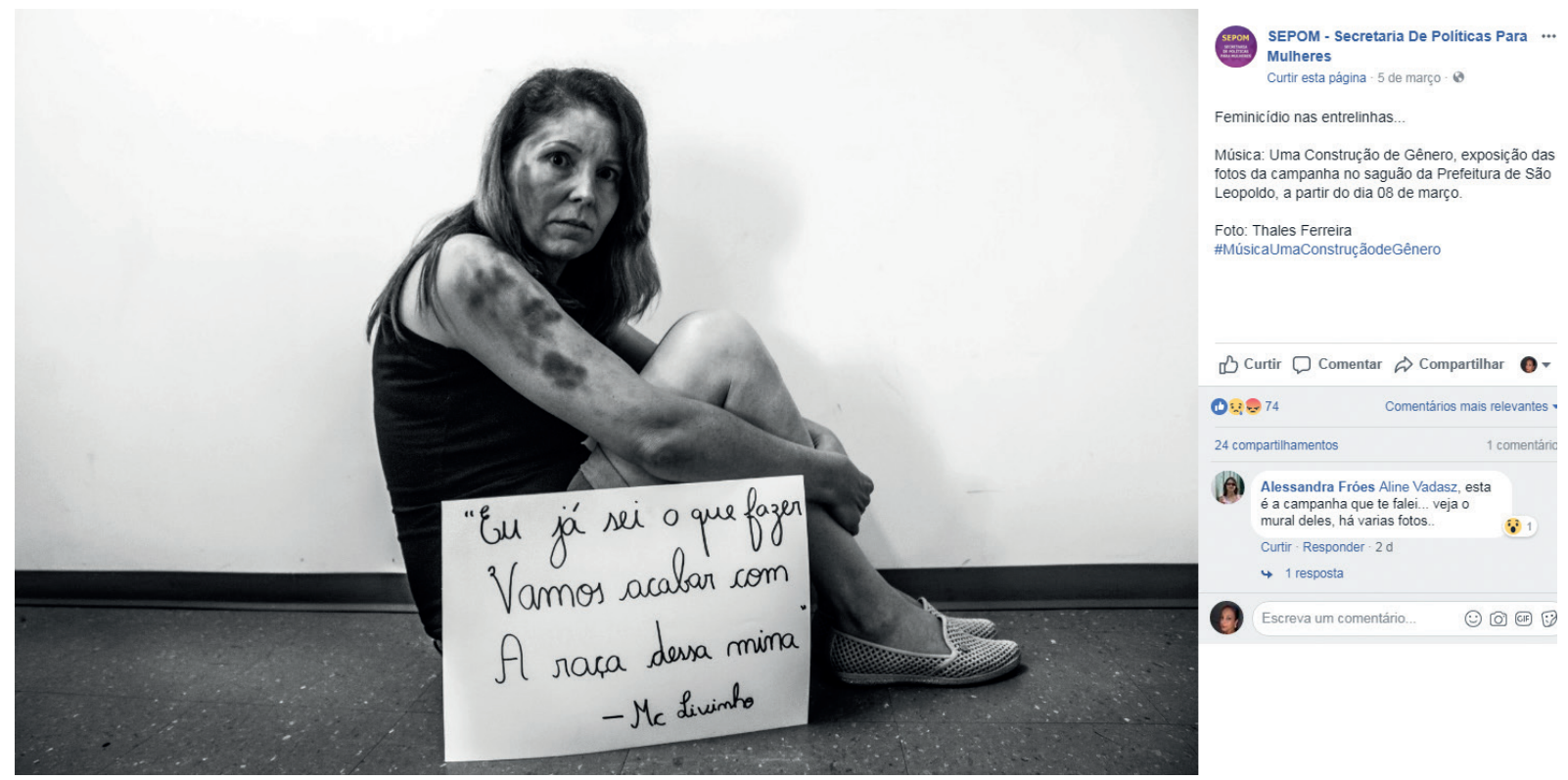

A música "Bandida”, de Mc Livinho, foi gravada com participaçāo do cantor Péricles. No dia da gravaçấo, Mc Livinho (funkeiro) diz que a parceria com o pagodeiro (Péricles) é uma forma de romper barreiras, dos ritmos e de preconceitos. Todavia, năo se rompe a barreira da violência contra a mulher, mas a sustenta fazendo samba e funk. Nos ritmos, o preconceito é rompido, mas năo o ódio que muitos homens parecer ter por mulheres. Esses cantam e sentem prazer ao dizer que "vamos acabar com a raça dessa mina". Mulher aqui passa a ser dita como raça, o que isso pode apontar no funcionamento das regularidades discursivas? Mais uma e outra forma de preconceito? Ora, sabemos que a marca linguística raça em geral aparece relacionada com a etnia negra, mobilizando um conjunto de efeitos negativos e depreciativos, tais como, preguiça, burrice ou limitaçăo, falta de beleza e pouco talento. Tais efeitos, tidos como naturalizados pela concepçăo escravagista branca, aqui aparecem deslocados e deslizam para atribuir sentidos a mulheres, no caso, "a raça dessa mina". Mais uma vez, observamos o feminicídio presente nos ritmos musicais de hoje e de ontem. 
Figura 4 - "Música: uma construçăo de gênero"

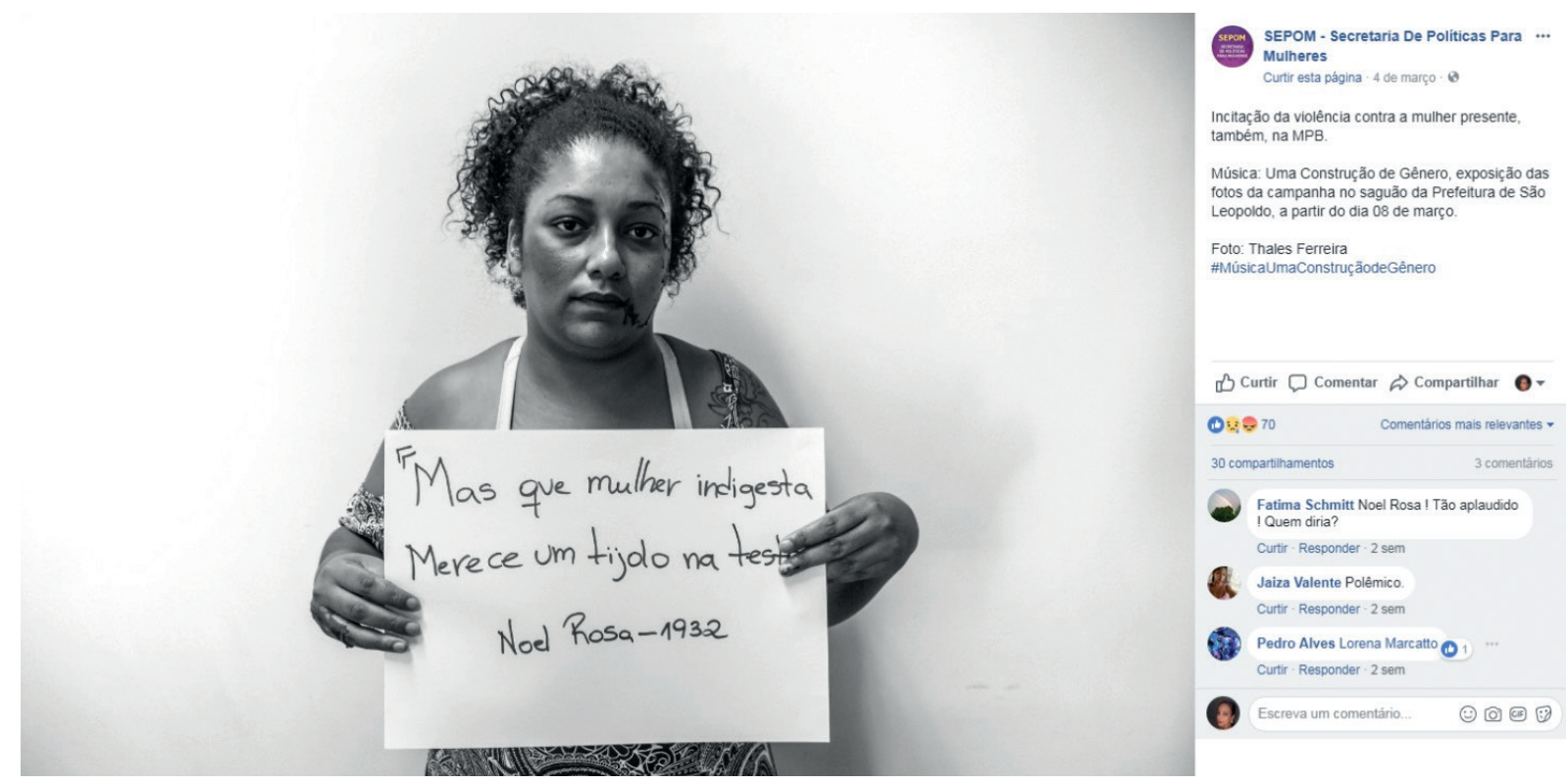

Em a “Mulher indigesta”, música de Noel Rosa, de 1932, a mulher indigesta (questionamos: a quem? A esse homem que canta esses refráos?) mereceria a violência. Muitos dizeres acerca da violência contra a mulher fazem uso do verbo "merecer", retomando uma memória sobre essa violência de gênero. Teríamos, na música de Noel Rosa, dois tipos de mulheres: a que merece tijolo na testa, por ser indigesta, e a que năo merece. É o homem que diz sua justificativa a esse merecimento: um comportamento da mulher que, provavelmente, questiona o poder masculino, por isso, ela é uma mulher indigesta. Questionamos a que sítios de significaçấo se filiam os dizeres de merecimento que permeiam as formulaçóes sobre a mulher? Há um jogo de forças entre a afirmativa e a negativa do merecimento. 0 merecimento é dito pelo outro e o náo merecer năo é dito pela mulher que é vítima da violência, muitas vezes, com sua morte. 
Figura 5 - "Música: uma construçâo de gênero"

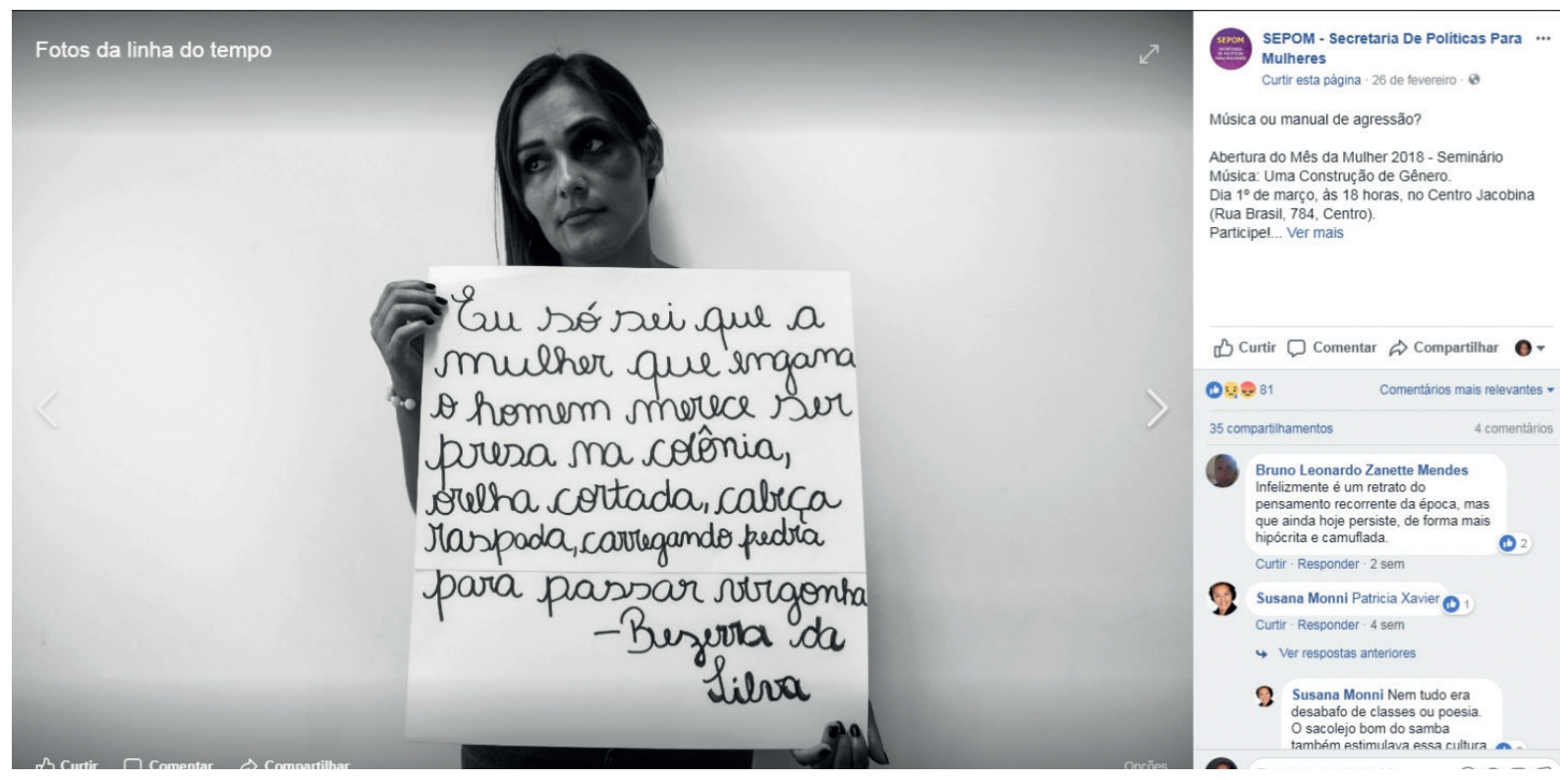

A música intitulada "Piranha", de Bezerra da Silva, também traz a apologia da violência contra a mulher e seu merecimento por "enganar o homem". Nos versos da música, temos a indicaçăo de diversas formas de violência contra a mulher (ser presa, ter a orelhada cortado, o cabelo raspado). Como um manual, a cançâo expóe um julgamento do homem a uma suposta culpa da mulher. Nos atos de violência, o objetivo é levar a mulher a "passar vergonha" como esse homem teria passado por causa dela.

Figura 6 - "Música: uma construçăo de gênero"

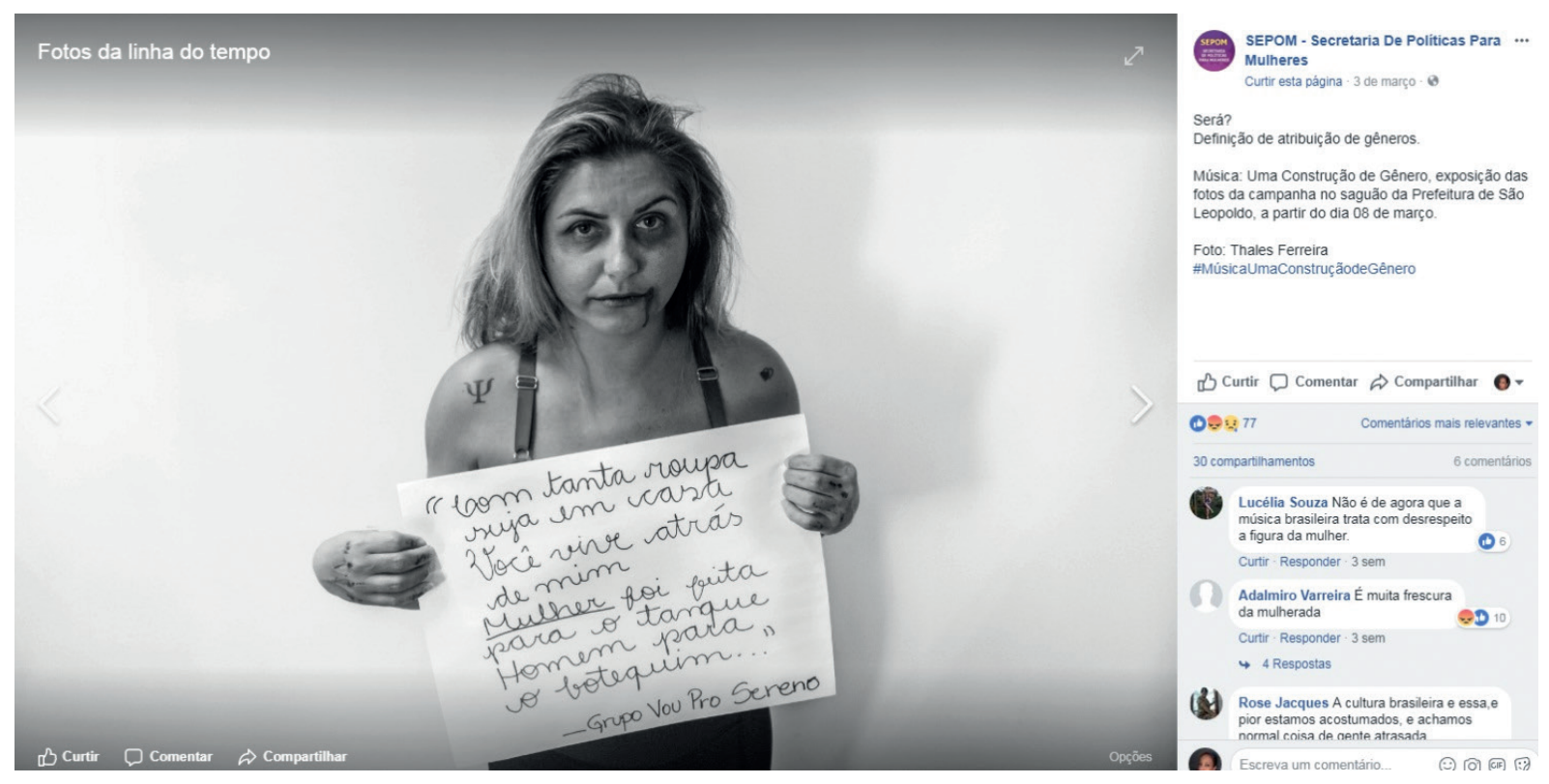


Já a música "Mulher năo manda em homem", do Grupo de pagode Vou Pro Sereno, circulou no ano de 2012. Em entrevista, Julio Sereno, vocalista do grupo, assim enuncia sobre a cançâo:

Năo acho que seja algo ofensivo, vejo como uma grande brincadeira. Hoje, as mulheres ocupam cargos importantes. Nos shows, elas cantam, dançam. Além disso, se um homem falar sério que lugar de mulher é no tanque corre o risco de apanhar ou ser preso. Na segunda parte, a gente troca a palavra e diz que a mulher foi feita para o shopping.

Como estabilizado na sociedade, por um funcionamento da memória, a violência contra a mulher é tratada, muitas vezes, como brincadeira, "mimimi". O homem, ao violentá-la por meio de palavras e gestos, restringindo essa mulher ao espaço do lar, enuncia-se como alguém que brinca sobre esse lugar, mas que sabe estarem as mulheres ocupando outros espaços. Com um dizer irônico, quase debochando de a sociedade ter considerado a música machista, o artista coloca em questionamento a credibilidade da mulher, como a duvidar que ela năo entendesse o "tom de brincadeira". Há um deslocamento da mulher que é vítima de uma violência que a encarcera no lar para a que é capaz de violentar o homem, o qual pode apanhar e ser preso por "brincar" com o lugar que a mulher pode ocupar (o que bem sabemos náo ser verdade, pois há inúmeros casos de feminicídio sem puniçăo, homens que năo săo presos por baterem em "suas" companheiras). Na resposta, temos também um deslizamento, por um efeito metafórico, de substituiçăo, do tanque (lar) para o shopping, retomando uma imagem da mulher consumista, que vive de fazer compras. Tanto na música como na entrevista dada pelo cantor, o machismo grita uma violência patriarcal de gênero. Outras duas cançôes em que temos também a violência legitimada é "Se essa mulher fosse minha", composiçâo de Martinho da Vila e "Silva Piranha", da banda Camisa de Vênus.

Figura 7 - "Música: uma construçāo de gênero"
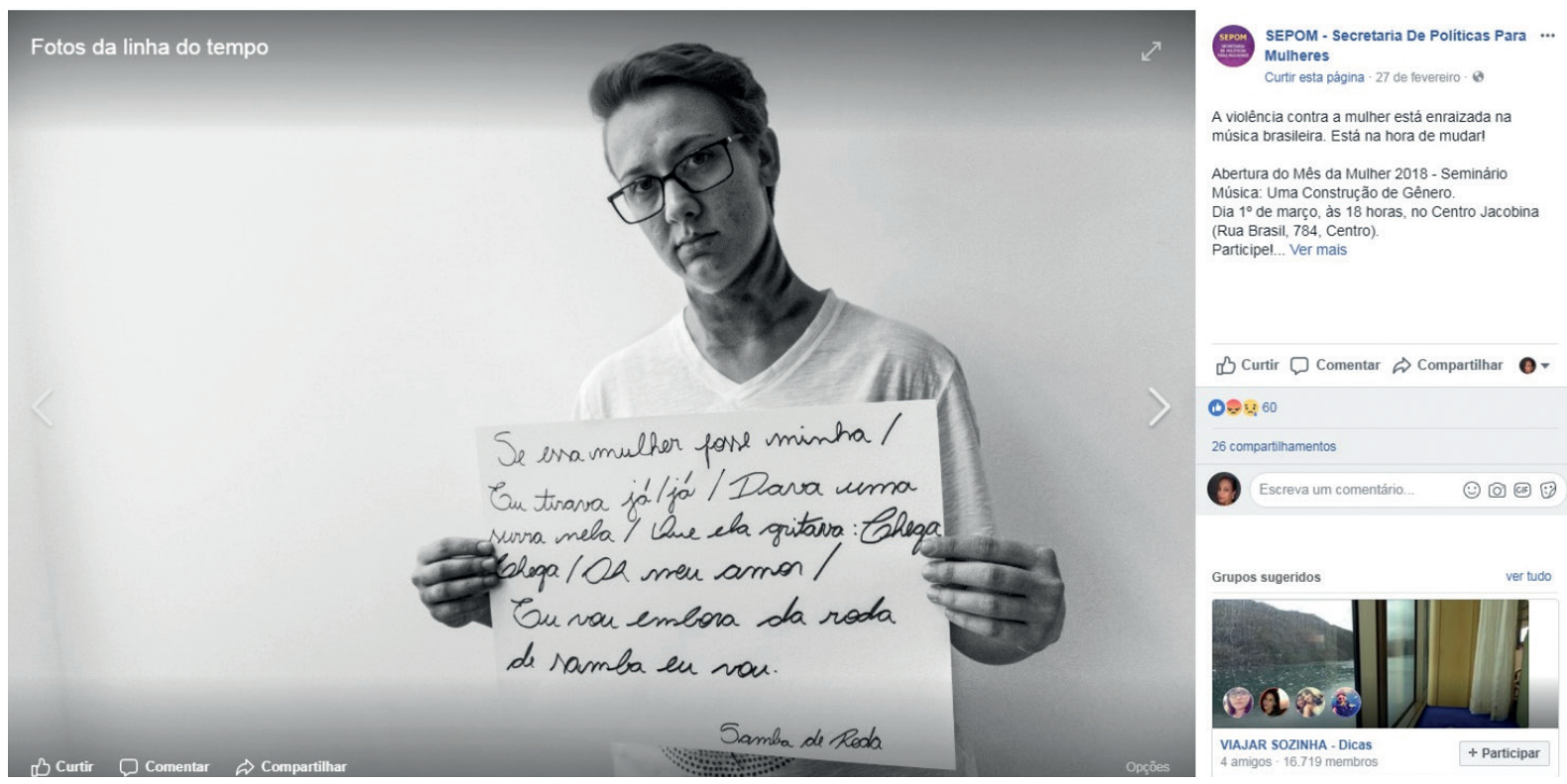

1 Disponível em: www.revista.cifras.com.br/5-musicas-consideradas-machistas-comentadas-por-mulheres 12399 . Acesso em 24 abr. 2018. 
Figura 8 - "Música: uma construçăo de gênero"

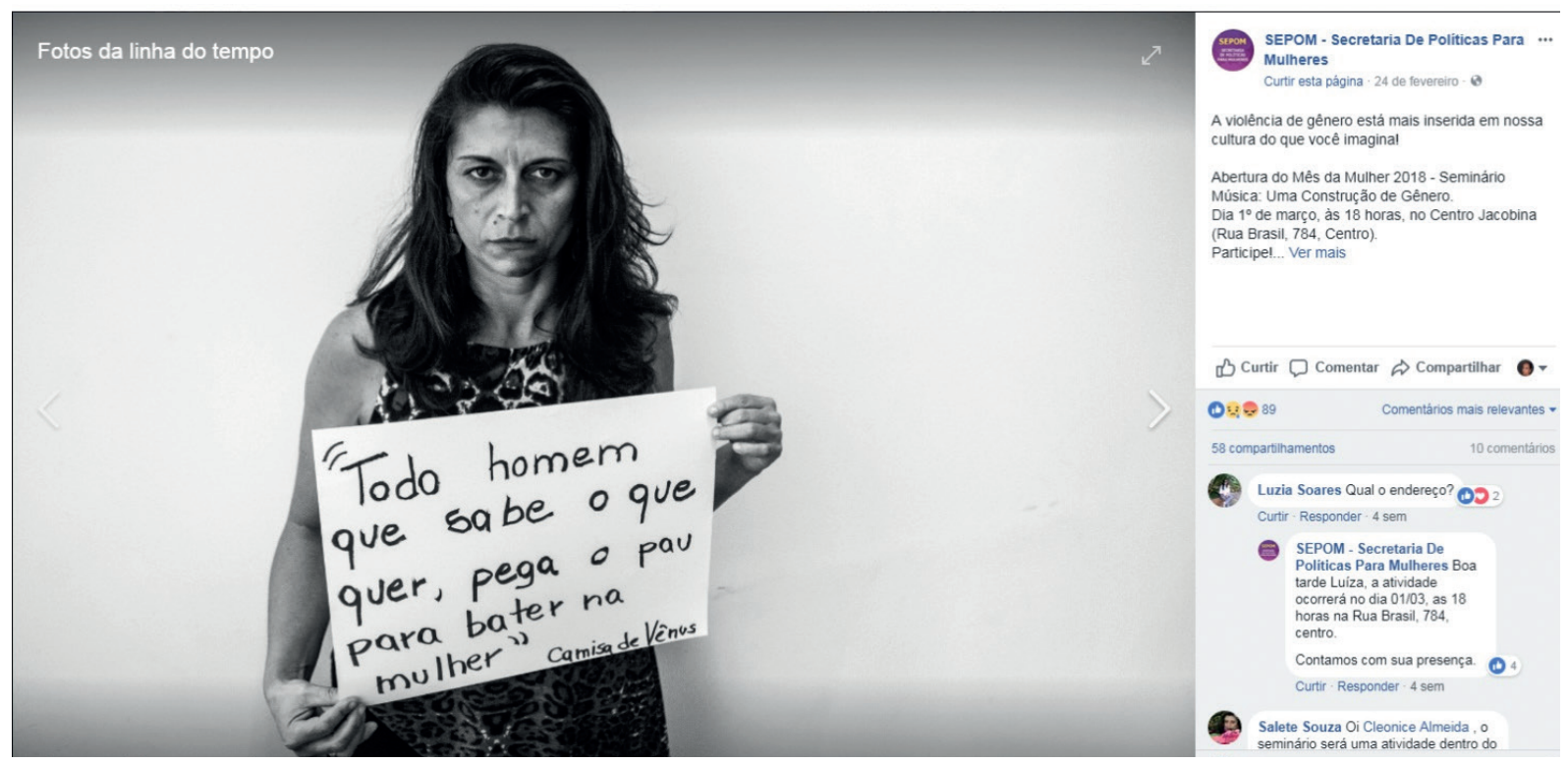

Pelo título da primeira, pelo uso da oraçáo condicional "se essa mulher fosse minha", temos a retomada de uma memória sobre como um homem deve agir com uma mulher (seja ela sua ou năo): bater com pau (e aqui vale a polissemia do significante), impedindo-a de estar no espaço da rua, do samba, de ter desejo por um outro homem (como vemos em "Silva Piranha": "Vive dizendo que me tem carinho / Mas eu vi você com a máo no pau do vizinho / Ô Silvia, piranha! / Todo homem que sabe o que quer / Pega o pau pra bater na mulher"). Por meio da violência, ao ser tratada como objeto, a mulher gritaria "Oh, meu amor", como a aceitar a violência para ainda sobreviver, apesar dos estupros, dos tapas, dos xingamentos que a sociedade legitima ao náo ouvir o náo da mulher, suas denúncias, suas "indigestōes". Em resumo, as músicas retomam uma memória da mulher como a responsável pela violência do homem contra ela ("essas filha da puta"). Esse homem macho a embebeda, depois a estupra (em uma "surubinha de leve") e a joga na rua como se fosse nada, pois esse năo aceita parar, năo aceita o nâo até ter seu gozo ao violentar a mulher. Nos funks (com ampla circulaçăo no ano de 2018), a apologia ao estupro táo legitimado na sociedade patriarcal brasileira, como um modo de marcar o corpo da mulher e dizer qual é seu lugar de pertencimento. 
Figura 9 - "Música: uma construçâo de gênero"

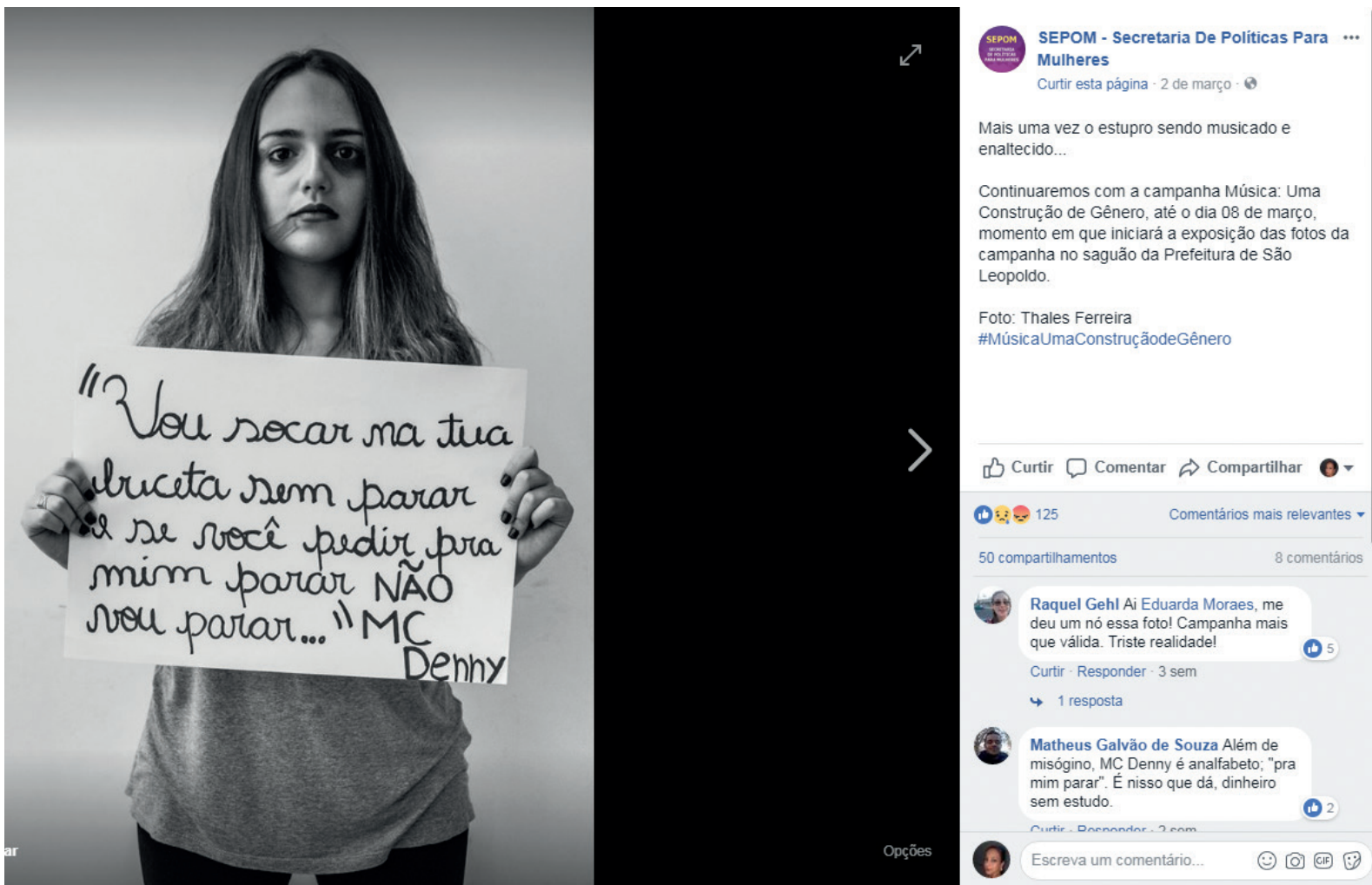

Figura 10 - "Música: uma construçăo de gênero"

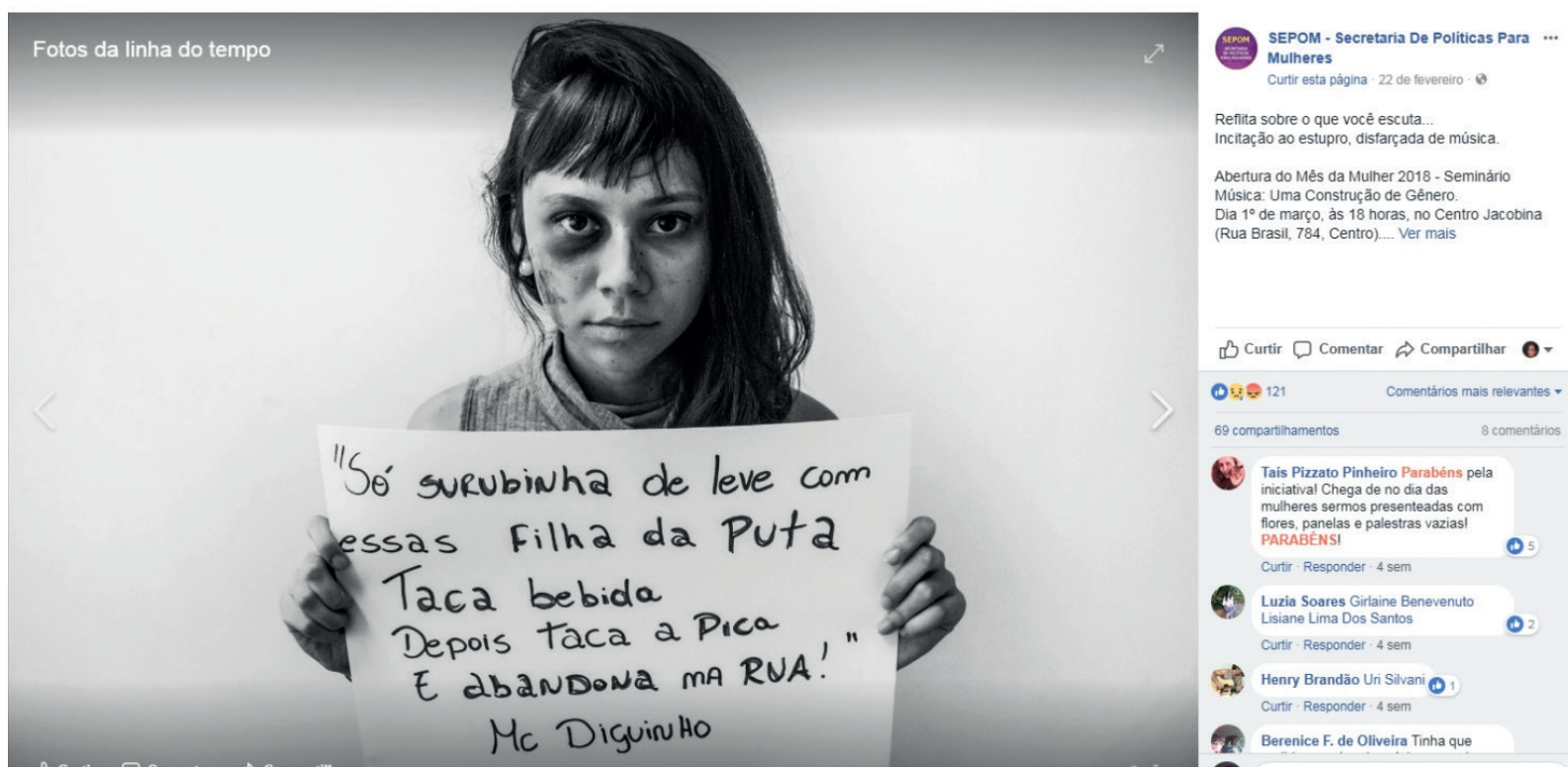


A mulher nas músicas é a que nâo é ouvida, a que é xingada, violentada de diferentes formas. Ao produzir "música", a circulaçăo de um modo de organizaçăo social de gênero, o qual é retomado em uma campanha produzida por uma instituiçáo governamental que visa a criar políticas para as mulheres. Como forma de tornar evidente essa violência contra a mulher, a campanha circula no ciberespaço, intentando furar uma memória tăo estabilizada e legitimada na sociedade brasileira acerca da mulher.

\section{CONSIDERAÇÕES FINAIS}

A violência contra a mulher está nos seus mais diferentes símbolos, segundo Dimenstein (1996), e está encravada no pensamento tipificado de homens e mulheres, herdeiros de uma sociedade que carrega pensamentos e crenças ultrapassados, que entendia a mulher como inferior ao homem, por esse motivo, portanto, a violência física, o estupro, os assassinatos, as torturas psicológicas e a mutilaçăo genital, entre outros atos de violência, sem falar na discriminaçăo contra a posiçâo feminina. Tais efeitos, tăo repetidos pela injunçâo ideológica que assegura a força fazer parecer naturalizado certo dizer e certa representaçăo imaginária, indiciam um modo de a história se inscrever na língua, produzindo evidências.

De acordo com Portela et al. (2011), o patriarcalismo sempre encontrou meios de preservar a sua continuidade, criando recursos cada vez mais relevantes de opressáo, isto é, afirmado diariamente pela mídia e até mesmo pela música, com letras que agridem a imagem da mulher, atribuindo-lhes figuras desmoralizadas, reforçando o discurso violentador dos homens contra as mulheres. Se historicamente a ideologia dominante fez parecer evidente e óbvio que a mulher esteja relacionada a esses efeitos de subjugaçăo e violência do homem, os movimentos de mulheres em luta - coletivos feministas de diferentes ordens, órgáos públicos, comissōes de defesas dos direitos humanos dentre outros - produzem um furo nessa consistência imaginária, nesse caso, revisitando músicas de ontem e hoje para deslocar seus sentidos originais. Há um litígio que se estabelece quando as fotografias inscrevem uma outra formaçăo discursiva, a saber, mostrando os corpos machucados, violentados e mortos de mulheres, colocando o sentido hegemônico em divisăo, em contradiçấo, em suspenso pela inscriçấo do político. Dar espaço para a circulaçăo desse litígio nos parece ser um modo produtivo de desestabilizar a cultura do ódio e violência em relaçâo à mulher. 


\section{REFERÊNCIAS}

ABRAHÂO E SOUSA; GARCIA, D. A. A sororidade no ciberespaço: laços feministas em militância. Estudos Linguísticos, v. 44, n.3, p. 991-1008, 2015.

LACAN, J. O seminário livro 5: as formaçôes do inconsciente (1957-1958). Rio de Janeiro: Jorge Zahar, 1999.

MOSTAFA, S. P.; AMORIM, I. S.; ABRAHÂO e SOUSA, L. M. Filosofia e discurso na Ciência da Informaçăo: tessitura de encontros. LOGEION. Filosofia da informaçâo, v.1, n.1, p. 6-19, 2014.

ORLANDI, E. P. Análise do discurso: princípios \& procedimentos. Campinas: Pontes, 2009.

ORLANDI, E. P. Discurso e texto: formulaçâao e circulaçâo dos sentidos. Campinas: Pontes, 2005.

PÊCHEUX, M. Análise automática do discurso. In: GADET, F.; HAK, T. (orgs.). Por uma análise automática do discurso: uma introduçâao à obra de Michel Pêcheux. Campinas: Editora da Unicamp, 2010 [1969].

PÊCHEUX, M. Papel da memória. In: ACHARD, P. (org.). Papel da memória. Campinas: Pontes, 1999.

ROMÂO, L.M.S. Nós, desconhecidos, na grande rede. Linguagem (em) Discurso. Tubarâo/SC. V. 5. p. 71-91, 2004.

ROMÂO, L.M.S.A paixăo inscrita no discurso da exposiçăo de/sobre Clarice Lispector. Ciência da Informaçăo e Literatura: Alínea, p. 31-56, 2012. Disponível em: http://dcm. ffclrp.usp.br/eladis/upload/LMS\%20Rom\%C3\%A3o.pdf. Acesso em: 28 maio 2018.

SAFFIOTI, H. L. B.; MUN̂OZ-VARGAS, M. (Org.). Mulher brasileira é assim. Rio de Janeiro: Rosa dos Tempos, 1994.

SAFFIOTI, H. L. B.; MUŇOZ-VARGAS, M. (Org.). ALMEIDA, S. S. (Org.) Violência de gênero. Poder e Impotência. Rio de Janeiro: Revinter, 1995.

SANTOS, C. M.; IZUMINO, W. P. Violência contra as mulheres e violência de gênero: notas sobre estudos feministas no Brasil. Estudios interdisciplinarios de América Latina y el Caribe, v. 16, n. 1, 2014.

DIMENSTEIN, G. Democracia em pedaços: direitos humanos no Brasil. Săo Paulo: Cia das Letras, 1996.

PORTELA, R. [et. al.]. O sexismo nas músicas de pagode em Salvador: discutindo a violência contra a mulher em sala de aula. 2011. Disponível em: https://nugsexdiadorim.files.wordpress.com/2011/12/o-sexismo-nas-mc3basicas-de-pagode-em-salvador-discutindo-a-violencia-contra-a-mulher-em-sala-de-aula.pdf. Acesso em: 02 maio 2018. 